\title{
UPAYA MASYARAKAT DALAM MENGHADAPI PANDEMI COVID-19 DALAM BIDANG PERTANIAN DI DESA SUNGAI PIRING
}

\author{
Rismawati \\ Jurusan Agroteknologi, Fakultas Pertanian, Universitas indragiri, Riau
}

Email: andiksamsunga10s@gmail.com

\begin{abstract}
Dampak dari pandemi covid-19 ini tidak hanya terkena pada perekonomian tetapi juga pendidikan dan bidang lain nya. Jika tidak ada kesadaran maka virus ini akan terus berkembang dan kehidupan tidak akan kembali normal. Kurang nya edukasi terhadap bahaya dari virus ini membuat masyarakat lengah. Hal ini terjadi secara jelas pada remaja yang berada dikelurahan sungai piring. Remaja yang seharusnya menyadarkan masyarakat untuk lebih tertib terhadap protokol kesehatan yang telah ditentukan namun masih saja belum terlaksana. Hal ini yang seharusnya lebih diperhatikan kembali. Oleh karena itu, tulisan ini akan mengangkat tema kesadaran remaja terhadap pematuhan protokol kesehatan.
\end{abstract}

Kata Kunci: Pandemi. Covid-19, perekonomian, kesehatan

\begin{abstract}
Abstrak
The impact of the Covid-19 pandemic is not only affecting the economy but also education and other fields. If there is no awareness, this virus will continue to grow and life will not return to normal. Lack of education on the dangers of this virus has caught people off guard. This is clearly the case for adolescents who live in the village of Sungai Piring. Adolescents who are supposed to make the community more orderly towards the health protocols that have been determined but still have not been implemented. This should be given more attention. Therefore, this paper will raise the theme of youth awareness of compliance with health protocols.

Keywords: Pandemic, covid-19, economy, healthy
\end{abstract}

\section{PENDAHULUAN}

\subsection{Latar Belakang}

Penyakit Virus Corona (Covid-19) tahun 2020 merebak virus baru coronavirPeus jenis baru (SARS-CoV-2) yang penyakitnya disebut Coronavirus disease 2019 (COVID-19). Virus in ditemukan di Wuhan, China pertama kali dan sudah menginfeksi 90.308 orang per tanggal 2 Maret 2020. Jumlah kematian mencapai 3.087 orang atau $6 \%$, jumlah pasien yang sembuh 45.726 orang. Virus jenis RNA strain tunggal positif ini menginfeksi saluran pernapasan manusia dan bersifat sensitif terhadap panas dan secara efektif dapat diinaktifkan oleh desinfektan mengandung klorin. Sumber host diduga berasal dari hewan terutama kelelawar, dan vektor lain seperti tikus bambu, unta dan musang. Gejala umum berupa demam, batuk dan sulit bernapas. Sindrom klinik terbagi menjadi tanpa komplikasi, pneumonia ringan dan pneumonia berat. Pemeriksaan spesimen diambil dari swab tenggorok (nasofaring dan orofaring) dan saluran napas bawah (sputum, bilasan bronkus, aspirat endotrakeal). Isolasi dilakukan pada pasien terbukti terinfeksi Covid-19 untuk mencegah penyebaran lebih luas.

Untuk pertama kalinya, China melaporkan adanya penyakit baru ini pada tanggal 31 Desember 2019. Pada pengujung tahun 2019, kantor Organisasi Kesehatan Dunia (WHO) di China mendapatkan pemberitahuan tentang adanya sejenis pneumoniayang penyebabnya tidak diketahui. Infeksi pernapasan akut yang menyerang paru-paru itu terdeteksi di kota Wuhan, Provinsi Hubei, China. Menurut pihak yang berwenang, beberapa pasien adalah pedagang yang beroperasi di Pasar Ikan Huanan. 
Pandemi Covid-19 berdampak langsung terhadap pendapatan masyarakat di Indonesia.Sebanyak $84 \%$ masyarakat Indonesia merasakan adanya penurunan pendapatan.Bahkan, 3 dari 10 orang mengaku pendapatan mereka berkurang lebih dari 50\%dibanding sebelum pandemi ini. Meskipun begitu, terdapat 49\%masyarakat Indonesia optimis pendapatan mereka akan kembali meningkat dalam enam bulan ke depan. Soeprapto Tan, Managing Director Ipsos di Indonesia, mengatakan, akibat pandemi Covid-19 ini, pertumbuhan ekonomi di Indonesia pada kuartal I 2020 melambat dibandingkan tahun sebelumnya. Hal ini disebabkan menurunya permintaan domestik dan konsumen rumah tangga, serta rasio investasi yang rendah.Berdasarkan hasil kuisioner di lapangan yang telah dilakukan oleh peneliti, ditemukan pokok permasalahan ekonomi yang terjadi dikarenakan dampak dari Covid-19 terhadapPendapatan masyarakat. Sebagai bukti, para pedagang buah yang ada dikelurahan sungai beringin mengaku bahwa sejak pandemi covid-19 ini terjadi, pendapatan mereka sangat berkurang.

penyebaran covid-19 ini sendiri. Jika tanpa kesadaran dari masyarakat untuk mencegah tersebar nya virus ini maka segala permasalahan yang terjadi tidak akan selesai. Dampak dari pandemi covid-19 ini tidak hanya terkena pada perekonomian tetapi juga pendidikan dan bidang lain nya. Jika tidak ada kesadaran maka virus ini akan terus berkembang dan kehidupan tidak akan kembali normal. Kurang nya edukasi terhadap bahaya dari virus ini membuat masyarakat lengah. Hal ini terjadi secara jelas pada remaja yang berada dikelurahan sungai piring. Remaja yang seharusnya menyadarkan masyarakat untuk lebih tertib terhadap protokol kesehatan yang telah ditentukan namun masih saja belum terlaksana. Hal ini yang seharusnya lebih diperhatikan kembali. Oleh karena itu, tulisan ini akan mengangkat tema kesadaran remaja terhadap pematuhan protokol kesehatan.

darurat pangan di tengah pandemi virus Korona (Covid-19). Pembatasan sosial dan skema penguncian (lockdown) yang diterapkan di banyak negara akan memengaruhi produksi pertanian global. Menurut World Food Summit (1996), ketahanan pangan terjadi ketika semua orang, setiap saat, memiliki akses fisik, sosial, dan ekonomi terhadap pangan yang cukup aman dan bergizi yang memenuhi kebutuhan sehari-hari dan preferensi makanan untuk kehidupan yang aktif dan sehat. Pemerintahan Presiden Joko Widodo (Jokowi) harus mampu secara cepat mengantisipasi sinyal FAO ini untuk menjaga ketersediaan bahan pangan dan menyelamatkan petani lokal. Meski pemerintah sudah memastikan stok sejumlah bahan pangan seperti beras, gula, daging, minyak goreng dan bawang putih mencukupi kebutuhan, faktor distribusi dan daya beli warga sangat memengaruhi aksesibilitasnya.Kenaikan harga bahan pangan di sejumlah daerah masih tergolong relatif kecil, namun pemerintah harus mewaspadai permainan para mafia pangan yang kerap menumpuk bahan kebutuhan dasar ini guna menjaga stabilitas harga di tingkat konsumen dan produsen pangan. Di tengah pandemi Covid-19 ini, disrupsi yang dihadapi petani akan kian kencang dan rantai pasok pangan akan mengalami gangguan yang serius yang pada gilirannya meningkatkan kepanikan sosial dan darurat pangan di tengah warga. Salah satunya di daerah Kepulauan Riau. Memperhatikan kondisi geografis Kepulauan Riau yang sebagian besar berupa laut dan struktur tanah bebatuan dan pertambanganmembawa konsekuensi keterbatasan sektor pertanian bergerak secara optimal. Dalam beberapa periode menunjukkan bahwa inflasi Kepri didominasi oleh kenaikan harga beras. Sehingga mengharapkan perhatian terhadap sektor pertanian ini dari para pemangku kepentingan perekonomian Kepri. Keterbatasan ketersediaan beras sebagai hasil panen atas yang ditanami sendiri oleh masyarakat di Kepri ini, tentu akan menurunkan daya beli masyarakat karena beras didapat dan di beli dengan harga cukup mahal dibandingkan dengan Provinsi lainnya di Pulau Sumatera. Sementara itu dilihat dari mata pencaharian masyarakat Kepri tergantung dari Nelayan, karena setiap Kabupaten/Kota terdiri dari beberapa pulau, dengan moda transportasi utamanya adalah dengan Kapal Laut dan Perahu. Seandainya cetak sawah di Kabupaten Lingga dan Natuna dapat berjalan dengan baik dan sesuai dengan perencanaan dana serta dioptimalkan penggunaannya untuk mencapai output yang telah ditentukan, maka program cetak sawah tersebut dapat memberikan konstribusi terhadap perekonomian rakyat khususnya dalam menjaga ketahanan pangan dan swasembada beras di Provinsi Kepulauan Riau terutama pada masa pandem covid 19 saat ini. 


\subsection{Identifikasi Masalah}

Berdasarkan pokok permasalahan yang telah dijelaskan diatas, maka terdapat beberapa pokok persoalan sebagai berikut:

1. Berkurangnya hasil pangan masyarakat sejak adanya pandemi covid-19

2. Turunnya tingkat kesehatan masyarakat yang membuat produksi di bidang pangan berkurang

3. Kendala dalam menghadapi covid-19 yang di lakukan oleh masyarakat agar ekonomi di sektor pertanian tetap berjalan lancar

\section{TINJAUAN PUSTAKA}

4.1. Ketahanan Pangan pada Covid-19

Klasifikasi Dunia saat ini sedang menghadapi pandemi covid-19. Pandemi ini tidak semata-mata berdampak pada sektor kesehatan, tetapi juga sosial ekonomi masyarakat. Di sektor pertanian, FAO sudah memperingatkan potensi krisis pangan global. Rantai pasokan pangan dunia juga terancam di tengah pemberlakuan karantina wilayah, pembatasan sosial, dan larangan perjalanan. Kebijakan tiap-tiap negara dalam mencegah penyebaran covid-19 turut berimplikasi pada kebijakan pangan maupun kemampuan produksi mereka. Realitas itu menunjukkan, ketahanan pangan sama pentingnya dengan kesehatan masyarakat. Jika dokter dan tenaga medis ialah tentara dalam upaya melawan penyebaran covid-19, begitu pun para petani, penyuluh, dan insan pertanian lainnya. Pertahanan yang penting dalam melawan covid-19 ialah ketahanan pangan. Dari sisi protokol kesehatan, pemerintah sudah menyiapkan strategi khusus untuk mencegah penyebaran virus melalui pembatasan sosial berskala besar (PSBB). Strategi itu hanya akan efektif sepanjang pangan pokok tersedia untuk rakyat. Menteri Pertanian Syahrul Yasin Limpo (SYL) dalam berbagai kesempatan selalu menegaskan keyakinannya, RI dapat melewati masa pandemi ini, bahkan keluar menjadi bangsa pemenang. Khususnya, untuk sektor pertanian, Mentan percaya kondisi ini bisa menjadi momentum memperkuat kemandirian pangan nasional. Saat ini, menurut Mentan SYL, semua insan pertanian harus tetap bekerja dengan semangat tinggi dan tangguh, untuk mewujudkan kemandirian pangan.

Kita membutuhkan tenaga ekstra keras, pemikiran-pemikiran out of the box, serta kerja sama yang semakin erat. Saatnya para petani, penyuluh, peneliti, akademisi, swasta, dan pelaku sektor pertanian lainnya untuk menjadi pahlawan bagi bangsa dan negeri ini dengan semangat kebersamaan. Produksi berbasis pertanian rakyat Presiden Jokowi sudah memberikan arahan bahwa pandemi covid-19 menjadi momentum reformasi sektor pangan. Indonesia dituntut memenuhi seluruh kebutuhan pangan dalam negeri. Maka, langkah utama yang perlu dilakukan meningkatkan produksi nasional berbasis pertanian rakyat dan keberpihakan pada petani kecil. Untuk bisa mewujudkannya, pemerintah sudah melakukan realokasi anggaran yang lebih besar untuk dialokasikan berupa bantuan benih/bibit, program padat karya, stabilisasi stok dan harga pangan, serta distribusi dan transportasi pangan. Realokasi anggaran itu menjadi modal pemerintah mendongkrak produktivitas pangan sekaligus meningkatkan kesejahteraan petani. Keberpihakan terhadap petani kecil pun harus ditunjukkan dengan optimalisasi peran penyuluh.

Pandemi covid-19 tidak boleh menjadi penghalang penyuluh untuk terus mendampingi petani. Kementan sudah memiliki wadah Kostratani yang dilengkapi teknologi informasi digital sehingga pendampingan bisa dilakukan kapan pun dan di mana pun. Langkah berikutnya yang juga berperan penting ialah optimalisasi lahan. optimalisasi seluruh lahan pertanian di Indonesia perlu gerakan antarlintas sektoral. Pemerintah daerah harus berkomitmen mendorong pemanfaatan lahan suboptimal, seperti lahan kering dan rawa, juga sekaligus mencegah terjadinya alih fungsi lahan pertanian. Pemanfaatan pekarangan dilakukan melalui upaya memberdayakan keluarga ataupun satuan kelompok masyarakat yang lebih besar untuk budi daya lahan pekarangan maupun pengolahan hasilnya. Upaya pemanfaatan Iahan dilakukan tidak hanya dengan berbudi daya berbagai jenis tanaman pangan dan hortikultura, tetapi juga, budi daya ternak dan ikan sehingga bisa mencukupi ketersediaan pangan, baik karbohidrat, protein, vitamin, maupun mineral. Kegiatan pemanfaatan lahan pekarangan bisa dilakukan keluarga sebagai unit kelompok masyarakat terkecil. Pemanfaatan Iahan pekarangan juga bisa dilakukan kelompok masyarakat, seperti warga permukiman, rusun, asrama, ataupun siswa sekolah, dan pondok pesantren. Berkali-kali Mentan Syahrul juga menegaskan perlunya mengantisipasi dan memetakan daerah rawan pangan dan alokasi kebutuhan pangannya secara tepat. Untuk mengurangi potensi kerawanan pangan, masyarakat 
perlu didorong untuk mampu secara mandiri memenuhi kebutuhan pangan. Salah satunya mendorong masyarakat memperkuat cadangan pangan masyarakat melalui kegiatan Lumbung Pangan Masyarakat (LPM).

LPM dibangun untuk mendekatkan akses pangan ke anggota kelompok tani dan membangun kesadaran masyarakat tentang pentingnya cadangan pangan terutama di masa krisis. Melalui keberadaan LPM, masyarakat bisa menjaga kontinuitas ketersediaan dan akses pangan masyarakat, khususnya di wilayah perdesaan. Dalam kondisi pandemi, juga dibutuhkan lebih banyak inovasi dan terobosan untuk memastikan distribusi kebutuhan pangan bisa merata ke wilayah rawan pangan dan masyarakatnya. Sebagai awal, Kementan bekerja dengan TNI-AD telah meluncurkan ATM Beras. Salah satu upaya membantu masyarakat yang mengalami keterbatasan akses pangan selama mengikuti kebijakan PSBB. Kita harapkan inovasi dan terobosan, serta sinergi dengan $\mathrm{K} / \mathrm{L}$ lain, BUMN, dan sektor swasta bisa terus kita giatkan sehingga tingkat kerawanan pangan bisa kita tekan. Keberpihakan pada petani Pandemi covid-19 juga telah berpengaruh pada fluktuasi harga komoditas-komoditas pangan. Disparitas harga antara produsen atau petani dan masyarakat konsumen menjadi lebar. Pemberlakuan PSBB di sejumlah wilayah berimplikasi terhambatnya distribusi dari sentra produksi ke wilayah perkotaan sebagai sentra konsumsi. Untuk itu, sektor usaha pertanian perlu beradaptasi dengan perubahan ini. Kita harus bisa menciptakan efisiensi rantai pemasaran produk pertanian dengan tetap keberpihakan pada petani. Upaya yang sudah dilakukan Kementan untuk menciptakan efi siensi rantai pemasaran, antara lain mengoptimalkan dan memperluas Pasar Mitra Tani dan Toko Tani hingga bisa mencakup 34 provinsi. Pasar Mitra Tani selama ini menjadi penghubung bagi Gapoktan yang ingin menjual produk mereka secara langsung ke konsumen. Di era digital, kita juga terbantu dengan hadirnya sejumlah layanan antarberbasis online. Untuk itu, Kementan terus mendorong efi siensi rantai pemasaran turut memfasilitasi kerja sama antara petani dan produsen dengan sejumlah layanan antarberbasis online, seperti Go-Jek, Grab, Blibli, dan Tokopedia. Upaya lain yang dilakukan, memfasilitasi dan bekerja sama dengan startup yang bergerak di rantai pemasaran.

Kondisi PSBB turut berpotensi pada rendahnya daya serap pasar terhadap hasil produk petani. Startup bisa membantu menyerap hasil produk tani sehingga harga di tingkat petani pun tetap stabil. Yang tidak boleh dilupakan dalam menjaga ketahanan pangan selama pandemi covid-19 ialah memastikan petani kita tetap sehat, sejahtera, dan semangat agar tetap terus berproduksi. Kedaulatan pangan akan sulit diwujudkan jika petani sebagai pelaku utama usaha tani tidak sejahtera. Maka, negara harus hadir untuk menjamin kesejahteraan petani, menjaga semangat mereka, dan memastikan kesehatannya.

\subsection{Dampak Covid-19 di Bidang Pertanian}

Indonesia adalah negara agraris yang memberi konsekuensi pertumbuhan kehidupan hampir keseluruhan masyarakat Indonesia, maka perlunya perhatian pemeritah pada sektor pertanian yang kuat dan tangguh. Oleh karena itu, salah satu sektor yang mendukung pertumbuhan ekonomi adalah sektor pertanian.

Indonesia merupakan negara pertanian, hal ini berarti petani memegang peranan yang amat penting dari keseluruhan perekonomian nasional Indonesia. Hal ini, ditunjukan dari banyakbanyak rakyat atau tenaga kerja pada sektor pertanian. Petani dan pertanian merupakan basis besar perekonomian Indonesia. Bila saja sistem agribisnis ini bisa mendapatkan perhatian dari pemerintah, maka kita bisa mandiri dalam hal pemenuhan bahan makanan penduduk. Perhatian pemeritah termasuk dalam menunjang sektor pertanian di bidang riset dan teknologi yang sepadan. Sebaiknya, kalau tidak ada perhatian besar pemeritah, jangan harap sektor ini bisa berkembang.

Prof. Zun Peneliti Pertanian di salah satu University Venezuela dan juga pemegang nabel dari PBB mengatakan bawa, sektor pertanian pasti akan tergilas kalau tidak ada perhatian yang tinggi dari pemeritah dalam suatu negara agraris. Bila pada titik itu ada bencana, maka barulah kita sadar betapa pentingnya bahan makanan yang dihasilkan oleh sektor pertanian.Maka dari itu, pembanguan sektor pertanian jangan dilupakan bahkan sangat perlu perhatian dan fokus pemeritah. Sebetulnya, Indonesia bisa menjadi negara maju, meski harus berbasis pertanian. Kalau hal itu dapat dilakukan, maka ada saatnya semua negara di sekitar Indonsia, akan sangat tergantung bahan pangannya dari bumi pertiwi ini. Selandia Baru, Vietnam, 
dan negara lainnya adalah contoh dari negara-negara yang pembanguan ekonomi berbasis pertanian.

Indonesia perlu membenahi pola pemberdayaan pertanian guna meningkatkan kualitas dan kuantitas hasil pertanian Indonesia untuk memenuhi kebutuhan makanan pokok di negara kita. Langkah awal yang perlu dilakukan adalah penyediaan benih, bibit dan tekhnik budidaya hingga teknologi panen dan pasca panen. Pola pemberdayaan pertanian perlu dilakukan dengan sinergitas yang baik dari berbagai sektor untuk membangun pertanian. Seperti diketahui Kementrian Pertanian menunda perdagangan sayur, hewan dan buah-buahan menuju dan dari China dan juga negara-negara lain guna mencegah wabah Novel Coronavirus (Covid19) atau Corona masuk ke Indonesia.Keputusan ini diambil menyusul Organisasi kesehatan dunian atau WHO menetapkan status global (Pandemi) terkait Covid-19, Peluang ini akan meningkatkan kesejahteraan para petani beserta keluarganya. Kesempatan ini menjadi peluang pasar untuk beberapa bulan kedepan dan bahkan untuk pembangunan pertanian berkelanjutan.

Dengan adanya Virus ini yang menginfeksi ribuan sektor perekonomian dunia. Masyarakat Indonesia diharapkan tidak panik dengan stok pangan yang ada. Kita bisa mengambil pelajaran dari wabah virus yang menyebar ini, untuk meningkatkan kualitas dan kuantitas pertanian Indonesia sebagai pertanian yang unggul.

\subsection{Strategi Pertanian \\ Menghadapi Pandemi Covid-19}

dalam

Daerah pandemi covid-19. Pandemi ini tidak semata-mata berdampak pada sektor kesehatan, tetapi juga sosial ekonomi masyarakat. Di sektor pertanian, FAO sudah memperingatkan potensi krisis pangan global. Rantai pasokan pangan dunia juga terancam di tengah pemberlakuan karantina wilayah, pembatasan sosial, dan larangan perjalanan. Kebijakan tiap-tiap negara dalam mencegah penyebaran covid-19 turut berimplikasi pada kebijakan pangan kemampuan produksi mereka. Realitas itu menunjukkan, ketahanan pangan sama pentingnya dengan kesehatan masyarakat. Jika dokter dan tenaga medis ialah tentara dalam upaya melawan penyebaran covid-19, begitu pun para petani, penyuluh, dan lainnya.
Pertahanan yang penting dalam melawan covid-19 ialah ketahanan pangan. Dari sisi protokol kesehatan, pemerintah sudah menyiapkan strategi khusus untuk mencegah penyebaran virus melalui pembatasan sosial berskala besar (PSBB). Strategi itu hanya akan efektif sepanjang pangan pokok tersedia untuk rakyat. Menteri Pertanian Syahrul Yasin Limpo (SYL) dalam berbagai kesempatan selalu menegaskan keyakinannya, RI dapat melewati masa pandemi ini, bahkan keluar menjadi bangsa pemenang. Khususnya, untuk sektor pertanian, Mentan percaya kondisi ini bisa menjadi momentum memperkuat kemandirian pangan nasional. Saat ini, menurut Mentan SYL, semua insan pertanian harus tetap bekerja dengan semangat tinggi dan tangguh, untuk mewujudkan kemandirian pangan. Kita membutuhkan tenaga ekstra keras, pemikiran-pemikiran out of the box, serta kerja sama yang semakin erat. Saatnya para petani, penyuluh, peneliti, akademisi, swasta, dan pelaku sektor pertanian lainnya untuk menjadi pahlawan bagi bangsa dan negeri ini dengan semangat kebersamaan. Produksi berbasis pertanian rakyat Presiden Jokowi sudah memberikan arahan bahwa pandemi covid-19 menjadi momentum reformasi sektor pangan. Indonesia dituntut memenuhi seluruh kebutuhan pangan dalam negeri. Maka, langkah utama yang perlu dilakukan meningkatkan produksi nasional berbasis pertanian rakyat dan keberpihakan pada petani kecil. Untuk bisa mewujudkannya, pemerintah sudah melakukan realokasi anggaran yang lebih besar untuk dialokasikan berupa bantuan benih/bibit, program padat karya, stabilisasi stok dan harga pangan, serta distribusi dan transportasi pangan. Realokasi anggaran itu menjadi modal pemerintah mendongkrak produktivitas pangan sekaligus meningkatkan kesejahteraan petani.

Sumber: https:/gg/mediaindonesia.c om/read/detail/308928-strategi-pertanianmenghadapi-pandemi-covid-19 


\section{PEMBAHASAN}

Upaya dari Mahasiswa KKN Kelurahan Sungai Beringin dalam meninkatkan hasil produksi pertnian dimasa Pandemi Covid 19.

\section{Kebijakan}

generasi muda dapat berperan dalam pemutusan rantai pemasaran yang panjang. Generasi muda dapat mengumpulkan hasil pertanian suatu desa dan memasarkannya secara langsung pada konsumen akhir. Konsumen akhir yang dimaksud adalah suatu organisasi atau badan yang membutuhkan bahan pangan dalam jumlah banyak

\section{Strategi}

Dalam mencapai kebijakan yang diinginkan maka peneliti melakukan strategi yang terdiri dari dua cara yaitu:

- Wawancara dimana peneliti mencari informasi mengenai masalah yang terjadi di lapangan mengenai hasil produksi pertanian dimasa pandemi

- kelurahan sungai piring untuk Memberikan pemahaman dan edukasi mengenai bahaya dari pandemi covid $-19$.

\section{Upaya}

Peran oleh generasi muda sangat diharapkan oleh petani, khususnya di perdesaan. Para petani sejatinya telah memiliki pengetahuan yang baik mengenai budidaya pertanian. Namun, seiring dengan perubahan cuaca serta perubahan kondisi ekonomi menuntut petani untuk meningkatkan produksinya. Petani perlu menyadari bahwa kegitan pertanian tidak hanya memperthatikan teknik budidaya saja. Kesadaran petani akan pentingnya pemasaran hasil pertnaian perlu ditanamkan. Pemasaran hasil pertanian dapat menentukan pendapatan yang diperoleh petani. Pendapatan yang diperoleh menentukan kemampuan petani untuk membeli kebutuhan pangan. Selain itu, pendapatan tersebut juga merupakan salah satu faktor penentu keberlangan kegiatan pertanian karena berperan dalam permodalan finansial seperti untuk membeli benih, pupuk, dan pestisida. Kedua hal tersebut merupakan wujud dari pencapaian salah satu tujuan dari progam SGDs (Sustainable Development Goals) yaitu zero hunger.

Menumbuhkan kesadaran remaja di Kelurahan Sungai Piring dalam menanggulangi pandemi covid - 19. Kelurahan Sungai Piring merupakan salah satu kelurahan yang ada di Kecamatan Batang Tuaka Kabupaten Indragiri Hilir, provinsi Riau, Indonesia.

Kelurahan Sungai Piring merupakan salah satu Desa Maju dengan berbagai potensi Desa yang ada di Kecamatan Batang Tuaka Kabupaten Indragiri Hilir.

Berdasarkan hasil observasi dan wawancara yang saya lakukan bahwa tingkat kesadaran remaja di Kelurahan sungai piring belum optimal dalam menanggapi dan menjaga diri untuk terhindar dari pandemi covid 19.Dikarenakan remaja di kelurahan sungai piring masih banyak yang belum mengerti terhadap dampak dan bahaya dari pandemi covid - 19 dan banyak remaja yang masih sering berkumpul bersama tanpa ada jarak dan tidak menggunakan masker sebagai contoh mereka masih berperilaku seperti sebelum adanya pandemi covid - 19.Oleh karena itu, kami dari Mahasiswa KKN Kelurahan Sungai Piring menghimbau dan memberikan edukasi kepada remaja di kelurahan sungai piring mengenai jarak dan penggunaan masker yang di anggap tidak penting oleh mereka dan kami juga mengingatkan kepada pemerintah Kelurahan Sungai Piring untuk tetap gencar dan rutin melakukan sosialisasi kepada masyarakat khususnya untuk para remaja yang masih belum mengerti akan bahaya dari pandemi covid - 19 tentang pentingnya menjaga jarak dan menggunakan masker ketika sedang berkumpul dan dimanapun berada tetap selalu menggunakan masker demi untuk memutus rantai penyebaran pandemi covid - 19 di Kabupaten Indragiri Hilir Khusunya di Kelurahan Sungai Piring. Selain itu, kami dari mahasiswa KKN di Kelurahan Sungai Piring berupaya untuk memberikan edukasi kepada remaja sungai piring tentang pentingnya menjaga jarak dan penggunaan masker.

Beragamnya pemerintah desa yang terlibat aktif di tengah wabah Covid19 mengisyaratkan bahwa pemerintah punya kekuatan untuk melibatkan para pemerintah desa dari sektor pemerintah itu sendiri hingga pihak swasta. Pemerintah desa memiliki jenis yang berbeda sesuai dengan atribut yang mereka miliki. Ada tiga atribut untuk memetakan pemerintah desa dalam kasus ini, yaitu atribut kekuasaan (power), legitimasi (le gitimacy), dan urgensi (urgency).

Selain pemerintah pusat melalui berbagai lembaga seperti Kementrian Kesehatan, Gugus Tugas Covid-19, pemerintah daerah (provinsi, kota dan kabupaten) adalah stakeholder yang 
memiliki kekuasaan. Dengan kekuasaan ini seharusnya pemerintah mampu mengendalikan publik dalam hal kepatuhan untuk melakukan himbauan pemerintah terkait wabah Covid-19.

Misalnya imbauan yang diberikan kepada masyarakat untuk melakukan social distancing, Pembatasan Sosial Berskala Besar (PSBB) dan larangan mudik ke kampung halaman. Dengan berbagai macam alasan, masyarakat masih banyak yang tidak patuh untuk melakukan social distancing sebagai salah satu ikhtiar untuk memutus mata rantai penyebaran virus Corona.

Dalam masa pandemi Covid-19, media menjadi pihak yang sangat aktif membombardir masyarakat dengan berbagai macam informasi mengenai wabah ini. Mulai dari media massa konvensional seperti koran, radio, dan televisi sampai media baru dengan berbagai platformnya secara serentak membanjiri masyarakat dengan berbagai macam informasi terkait Covid-19.

\section{KESIMPULAN DAN SARAN}

\subsection{Kesimpulan}

Pandemi covid-19 juga telah berpengaruh pada fluktuasi harga komoditas-komoditas pangan. Disparitas harga antara produsen atau petani dan masyarakat konsumen menjadi lebar. Pemberlakuan PSBB di sejumlah wilayah berimplikasi terhambatnya distribusi dari sentra produksi ke wilayah perkotaan sebagai sentra konsumsi. Untuk itu, sektor usaha pertanian perlu beradaptasi dengan perubahan ini. Kita harus bisa menciptakan efisiensi rantai pemasaran produk pertanian dengan tetap keberpihakan pada petani. Upaya yang sudah dilakukan Kementan untuk menciptakan efi siensi rantai pemasaran, antara lain mengoptimalkan dan memperluas Pasar Mitra Tani dan Toko Tani hingga bisa mencakup 34 provinsi. Pasar Mitra Tani selama ini menjadi penghubung bagi Gapoktan yang ingin menjual produk mereka secara langsung ke konsumen. Di era digital, kita juga terbantu dengan hadirnya sejumlah layanan antarberbasis online. Untuk itu, Kementan terus mendorong efi siensi rantai pemasaran turut memfasilitasi kerja sama antara petani dan produsen dengan sejumlah layanan antarberbasis online, seperti Go-Jek, Grab, Blibli, dan Tokopedia. Upaya lain yang dilakukan, memfasilitasi dan bekerja sama dengan startup yang bergerak di rantai pemasaran. Kondisi PSBB turut berpotensi pada rendahnya daya serap pasar terhadap hasil produk petani. Startup bisa membantu menyerap hasil produk tani sehingga harga di tingkat petani pun tetap stabil. Yang tidak boleh dilupakan dalam menjaga ketahanan pangan selama pandemi covid-19 ialah memastikan petani kita tetap sehat, sejahtera, dan semangat agar tetap terus berproduksi. Kedaulatan pangan akan sulit diwujudkan jika petani sebagai pelaku utama usaha tani tidak sejahtera. Maka, negara harus hadir untuk menjamin kesejahteraan petani, menjaga semangat mereka, dan memastikan kesehatannya.

\subsection{Saran}

Peniliti menyadari bahwa laporan ini masih jauh dari kesempurnaan, karena mengingat kondisi dan keadaan yang masih belum stabil untuk mengambil data yang lebih detail dan lebih akurat. Untuk itu tidaklah mudah untuk mendapat informasi. Ditambah dengan pengetahuan dan wawasan yang kami miliki masih sangat terbatas. Oleh karena itu, kritik dan saran dari para pembaca sangat kami harapkan untuk perbaikan kedepannya.

\section{DAFTAR PUSTAKA}

1. Anwar, C. 2001. Budidaya Tanaman Pangan. Pusat Penelitian Karet, Medan.

2. Maslow Sains. Teraju: Oktober 2004

3. Maramis W.F. Catatan IImu Kedokteran Jiwa. Surabaya: Airlangga University Press; 2005.

4. Mangoensoekardjo. 1983. Pengendalian Gulma Diperkebunan. Yogyakarta: Kanisus

5. Meilin, araz. 2006. Studi dominasi dan tknik pengen dalian gulma pada perkebunan karet (studi kasus di desa tunas baru, kecamatan sekeman, Kabupaten muaro jambi, Provinsi jambi). Balai pengkajian teknologi pertanian jambi (bptp) Jambi.

6. Tjitrosoedirdjo, S., I. H. Utomo dan J. Wiroatmodjo (Eds). 1984. Pengelolaan Gulma di Perkebunan. Kerjasama Biotrop Bogor - PT Gramedia. Jakarta. 225 hlm. 